\title{
Environmental parameters conditioning microbially induced mineralization under the experimental model conditions*
}

\author{
Anna Otlewska ${ }^{\bowtie}$ and Beata Gutarowska \\ Institute of Fermentation Technology and Microbiology, Faculty of Biotechnology and Food Sciences, Lodz University of Technology, Łódź, \\ Poland
}

\begin{abstract}
Microbially induced calcium carbonate precipitation is one of the biomineralization types closely dependent on the parameters of the microenvironment. Minerals are precipitated as a product of environmental and bacterial cell interactions, however, this system has very little control via microorganisms. The aim of research was to determine the influence of abiotic factors $(\mathrm{pH}$, temperature, agitation speed of bacterial culture and calcium ion source) on the mineralization induced by Arthrobacter sulfureus, Bacillus muralis and B. atrophaeus strains under the standard laboratory conditions. Because of the key role of urease in biomineralization, processes occurring in environments with and without the urea were compared. For this purpose, cultivation of bacteria ( $A$. sulfureus, B. muralis and B. atrophaeus) was carried out in B4 liquid medium for 5 days with various environmental parameters $\left(\mathrm{pH} \mathrm{6-9}\right.$; temperature $25-44^{\circ} \mathrm{C}$; speed of agitation $0-180 \mathrm{rpm}$, different calcium sources). It was noticed that the $\mathrm{pH}$ and the speed of agitation clearly affect the amount of the calcium carbonate that formed. Our observations suggest that the highest precipitation rate takes place in alkaline $\mathrm{pH}$ between $8-9$, with shaking at 180 rpms. Among studied sources of calcium ions (calcium acetate, calcium chloride and calcium nitrate), calcium acetate demonstrated the strongest potential in the biomineralization process. Moreover, work presented here demonstrates that the correlation between cultivation temperature and biomineralization process cannot be clearly evaluated. The morphology and size of calcium carbonate minerals was strain-specific, although affected by the presence of urea in the surrounding solution.
\end{abstract}

Key words: microbially induced mineralization, calcium carbonate, abiotic factors, urease

Received: 07 August, 2015; revised: 24 September, 2015; accepted: 06 October, 2015; available on-line: 19 February, 2016

\section{INTRODUCTION}

Biomineralization (synthesis of crystalline structures by living organisms) is a common phenomenon, occurring in different natural environments such as soil, sedimentary and metamorphic rocks, oceans, seas and saline lakes (Rivadeneyra et al., 2004; Baskar et al., 2005). According to Lowenstam \& Weiner (1989) biomineralization was classified as a biologically controlled and induced process. This division is based on the degree of biological control over the biominerals' secretion system by organisms. In a biologically controlled mechanism, biomineral precipitation happens due to the cellular activities of the organisms, producing a macromolecular matrix outside the cell, within or on which inorganic particles are grown (Young \& Henriksen, 2003). In this type of biomineralization, the gene responsible plays an effective role in deciding on the structure and composition of the mineral particles. The secreted minerals are unique to the bacterial species and are independent of environmental conditions (De Muynck et al., 2010; Sarayu et al., 2014). In contrast, biologically induced biomineralization is closely dependent on parameters of the microenvironment. Minerals are precipitated as a product of the interaction between environmental and biological activity and the system has very little control via microbial cells over the minerals that are secreted. Moreover, any change in the microenvironment will have an effect on the biominerals that are precipitated. An example of this type of biomineralization process is the formation of calcium carbonate $\left(\mathrm{CaCO}_{3}\right)$ by microorganisms, mainly bacteria (Bacillus subtilis, B. cereus, B. sphaericus, B. megaterium, Pseudomonas putida, Sporosarcina pasteurii, Myxococcus xanthus, Arthrobacter sp., Micrococcus sp.) (Hammes et al., 2003; Rivadeneyra et al., 2004; Baskar et al., 2005; Dhami et al., 2013). However, the precise role of microbes in the carbonate precipitation process still remains unclear (Konhauser \& Riding, 2012). Boquet et al. (1973) suggested that almost all bacteria are capable of $\mathrm{CaCO}_{3}$ formation. Several authors concluded that this phenomenon occurs as a by-product of different bacterial processes such as photosynthesis, urea hydrolysis, sulfate reduction and anaerobic sulphide oxidation (Castanier et al., 1999; Knorre \& Krumbein, 2000; Baskar et al., 2006). As a result of these metabolic processes, there is an increase in the $\mathrm{pH}$ value of a microenvironment, which favors $\mathrm{CaCO}_{3}$ precipitation.

Calcium carbonate precipitation mediated by microorganisms is governed by several key factors. According to De Muynck et al. (2010), there are four main factors in calcium carbonate formation: (1) the calcium concentration, (2) the concentration of dissolved inorganic carbon, (3) $\mathrm{pH}$, (4) the availability of nucleation sites. Dhami et al. (2013) and Hammes \& Verstracte (2002) also mention $\left[\mathrm{Ca}^{2+}\right] /\left[\mathrm{CO}_{3}{ }^{2-}\right]$ ratio and bacterial species in the saturation index as a factor. It is unknown how abiotic factors directly determining bacterial growth may affect the biomineralization process.

e-mail: anna.otlewska@p.lodz.pl

*The results were presented at the 6th International Weigl Conference on Microbiology, Gdańsk, Poland (8-10 July, 2015).

Accession numbers: KM036067 (A. sulfureus W4/124), KM036069 (B. atrophaeus II/39/3), and KM036074 (B. muralis I/2/3)

Abbreviations: LB, Luria-Bertani medium; EDTA, ethylenediaminetetraacetic acid 
Hence, the question has to be raised: is there a connection between environmental conditions (such as temperature, $\mathrm{pH}$, speed of agitation and calcium ions source), bacterial species, and microbially induced calcium carbonate precipitation?

The aim of this research was to determine the influence of environmental parameters $(\mathrm{pH}$, temperature, agitation speed of bacterial culture and calcium ion source) on the mineralization induced by Arthrobacter sulfureus, B. muralis and B. atrophaeus strains in the experimental model conditions. Moreover, in relation to the hypotheses generated by researchers on the key role of urease activity, biomineralization process was compared in environments with and without the urea.

\section{MATERIALS AND METHODS}

Bacterial strains. Bacterial strains used in this study were Arthrobacter sulfureus W4/124, B. atrophaeus II/39/3, and $B$. muralis $I / 2 / 3$. The strains were maintained in the Luria-Bertani medium (LB) supplemented with $15 \%$ $(\mathrm{v} / \mathrm{v})$ glycerol and stored at $-80^{\circ} \mathrm{C}$. Pre-cultures of bacteria were conducted in $30 \mathrm{~mL}$ of $\mathrm{LB}$ medium at $30^{\circ} \mathrm{C}$ with constant shaking at $150 \mathrm{rpm}$ for $24-48 \mathrm{~h}$. When the cells reached late exponential growth phase, the bacterial cultures were used for the following experiments.

Experimental system. Two types of experimental systems were designed: with and without $2 \%$ urea to accelerate urease production. The medium and urea solutions were sterilized separately. Urea was added after sterilization by means of filtration through a sterile $0.22 \mu \mathrm{m}$ Milipore filters. Regarding the study of the $\mathrm{CaCO}_{3}$ precipitation, bacterial cultures were carried out in $60 \mathrm{~mL}$ of liquid medium B4, containing calcium ions at concentrations ranging from 2.2 to $2.7 \mathrm{~g} / \mathrm{L}$ (Lee, 2003). The B4 medium was inoculated with $3 \%(\mathrm{v} / \mathrm{v})$ of bacterial pre-culture and incubated for 5 days at variable process parameters ( $\mathrm{pH}$ of culture medium, temperature, speed of agitation, and type of calcium source). Process parameters depending on the studied factors are shown in Table 1.

Qualitative urease activity assay. Urease activity of studied strains was determined on Christensen's Urea Agar Base (Merck). A fresh culture of bacteria was inoculated onto Christensen medium slants and incubated at $30^{\circ} \mathrm{C}$ for $72 \mathrm{~h}$. The reaction was recorded as positive after the appearance of a deep pink color (Atlas, 2010).

Analytical methods. Cell growth was determined by the plate counting method at regular time intervals of $24 \mathrm{~h}$ for 5 days of incubation. The results are expressed as a mean value of three replicates and presented as $\log$ $\mathrm{cfu} / \mathrm{mL}$ in a graphic form.

The soluble $\mathrm{Ca}^{2+}$ was measured using ethylenediaminetetraacetic acid (EDTA) titration method (APHA, 1989; Stocks-Fischer et al., 1999). Insoluble $\mathrm{Ca}^{2+}$ (as $\mathrm{CaCO}_{3}$ ) was derived as the difference between the total initial $\mathrm{Ca}^{2+}$ concentration and the concentration of soluble $\mathrm{Ca}^{2+}$.

Analysis of calcium carbonate crystals. Calcium carbonate crystals and bacterial cells were separated using Miracloth filtration materials (Calbiochem), washed and dried at $37^{\circ} \mathrm{C}$ for $48 \mathrm{~h}$. The morphology of crystals was analyzed using optical microscopy (Olympus CX41). The crystal size was determined using $\mathrm{Cell}^{\wedge} \mathrm{B}$ Image Acquisition Software (Olympus).

Statistical analysis. All statistical analyses were carried out using 3-way ANOVA at the confidence level of $p<0.05$. The results of the experiments were presented as the arithmetic mean of three assays.

Kinetics of the calcite precipitation were described by a modified sigmoid logistic curve. The exponential logistic equation:

$$
y=\frac{a}{1+e^{-b(x-c)}}+d
$$

where $\mathrm{a}$ is the range of $\mathrm{y}$ variation $\mathrm{Ca}^{2+}$; $\mathrm{b}$ is $\mu$ (precipitation rate, $\left.\mathrm{h}^{-1}\right) ; \mathrm{x}$ is time $(\mathrm{h}) ; \mathrm{c}$ is the time at the maximum $(\mathrm{dy} / \mathrm{dt}) ; \mathrm{d}$ is the initial concentration of $\mathrm{Ca}^{2+}$ at time zero and was used for calculation of the rate of calcium carbonate formation (Stocks-Fischer at al., 1999). The regression analysis was performed with Origin 2015, v. 9.2 software (OriginLab Corporation, USA).

In order to compare bacterial growth curves, the Gompertz equation in conjunction with DMFit ver. 2.1. Excel add-in program, was used (www.ifr.ac.uk/Safety/ DMfit/default.html., Baranyi \& Roberts, 1994). The Gompertz parameter values were used to calculate maximum specific growth rates $\left(\mu_{\max }\right)$, lag phase durations $\left(\mathrm{T}_{\text {lag }}\right)$ according to Zaika et al. (1998).

\section{RESULTS AND DISSCUSION}

The bacterial strains of $A$. sulfureus W4/124, B. atrophaeus II/39/3 and B. muralis $\mathrm{I} / 2 / 3$ used in this study were isolated from historical building materials (brick, mortar, and plaster coated paint). Taxonomic position of the examined strains was defined by $16 \mathrm{~S}$ rRNA gene sequencing. The nucleotide sequences of genes were deposited in the GenBank Database, at the National Center for Biotechnology Information (NCBI) under the accession numbers KM036067 (A. sulfureus W4/124),

Table 1. Environmental conditions used in study of the biomineralization process

\begin{tabular}{|c|c|c|c|c|}
\hline \multirow{2}{*}{ Analyzed factor } & \multicolumn{4}{|c|}{ Parameters of bacterial cultivation } \\
\hline & $\mathrm{pH}$ of medium & Temperature of incubation $\left[{ }^{\circ} \mathrm{C}\right]$ & Speed of agitation [rpm] & Source of calcium ions \\
\hline $\mathrm{pH}$ & $6,7,8,9$ & 30 & 150 & calcium acetate \\
\hline Temperature & 7 & $25,30,37,44$ & 150 & calcium acetate \\
\hline Speed of agitation & 7 & 30 & $0,100,180$ & calcium acetate \\
\hline Source of calcium ions & 7 & 30 & 150 & $\begin{array}{l}\text { calcium acetate } \\
\text { calcium chloride } \\
\text { calcium nitrate }\end{array}$ \\
\hline
\end{tabular}



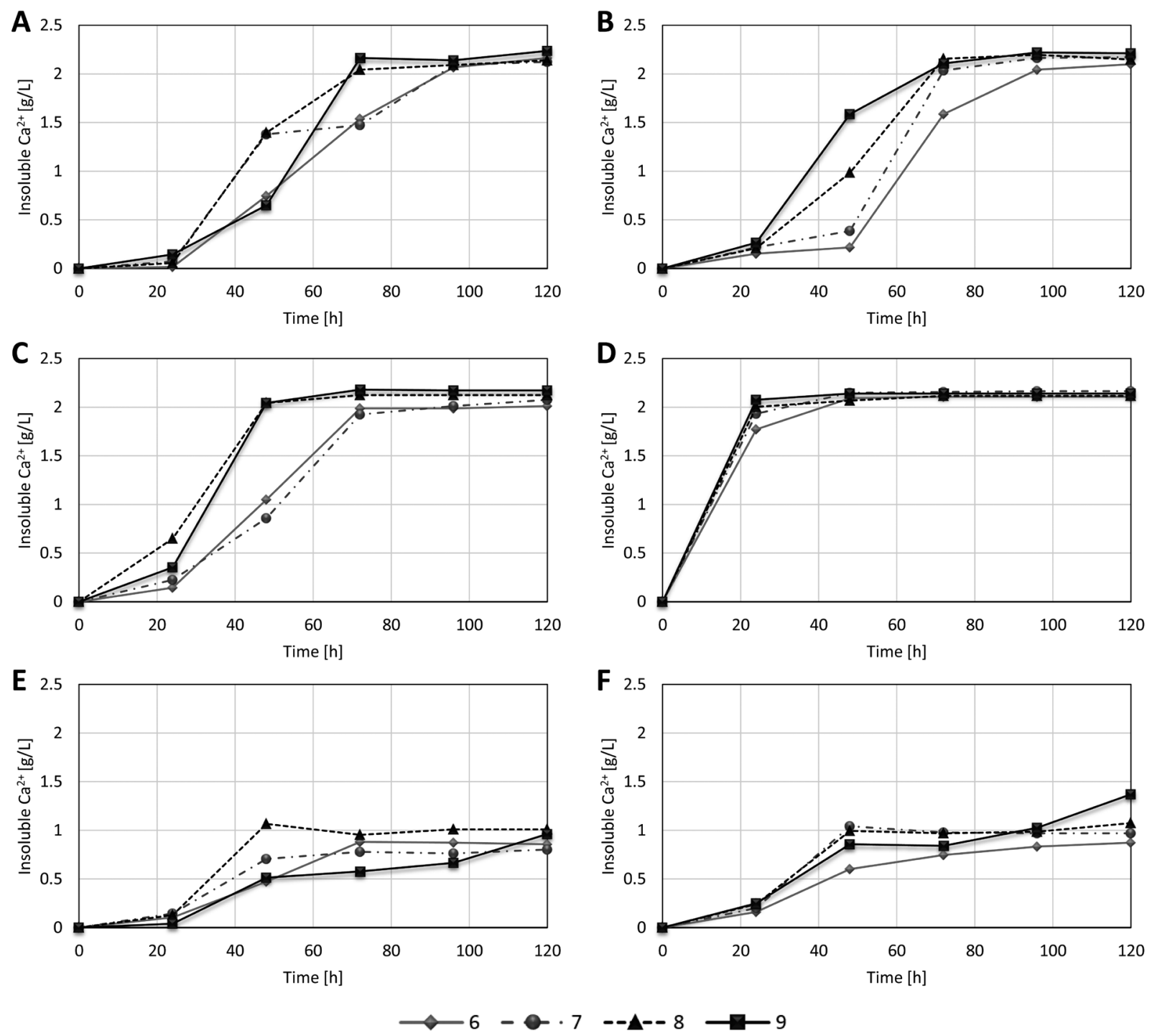

Figure 1. Time courses of mineralization induced by $B$. muralis $(\mathbf{A}-\mathbf{B}) ; A$. sulfureus $(\mathbf{C}-\mathbf{D})$, and B. atrophaeus $(\mathbf{E}-\mathbf{F})$ in various $\mathrm{pH}$ of a given medium. Medium without urea $(\mathbf{A}, \mathbf{C}, \mathbf{E})$ and supplemented with urea $(\mathbf{B}, \mathbf{D}, \mathbf{F})$.

KM036069 (B. atrophaeus II/39/3), and KM036074 (B. muralis $\mathrm{I} / 2 / 3$ ). All studied strains: $A$. sulfureus, B. muralis and $B$. atrophaeus, revealed urease activity on Christensen's Urea Agar Base. Enzymatic hydrolysis of urea is a well-known process of biomineralization and is a straightforward model for studying microbial calcium carbonate formation. During this process, hydrolysis of urea is caused by an enzyme - urease (urea amidohydrolase; EC 3.5.1.5). One mole of urea $\mathrm{CO}\left(\mathrm{NH}_{2}\right)_{2}$ is hydrolyzed intracellularly to one mole of ammonia $\mathrm{NH}_{3}$ and one mole of carbamate $\mathrm{NH}_{2} \mathrm{COOH}$, which in turn hydrolyzes into one mole of ammonia $\mathrm{NH}_{3}$ and carbonic acid $\mathrm{H}_{2} \mathrm{CO}_{3}$. These products subsequently equilibrate in water to form biscarbonate and two moles of ammonium and hydroxide ions. An increase in alkalinity causes a shift in the biscarbonate equilibrium resulting in a carbonate ion formation, and in the presence of soluble ions precipitating as calcium carbonate (Hammes et al., 2003; Dhami et al., 2013). Due to the key role of urease in biomineralization, the assay under the experimental model conditions was conducted with and without urea in the environment.

\section{Kinetics of calcite precipitation and bacterial growth in various $\mathrm{pH}$ of the surrounding solution}

The biomineralization phenomenon was observed for all studied strains in the experimental system, both with and without urea in the environment. After $120 \mathrm{~h}$ of cultivation in the presence of $2.3 \mathrm{~g} / 1$ of soluble $\mathrm{Ca}^{2+}$, insoluble calcium carbonate of between 2.0 to $2.3 \mathrm{~g} / \mathrm{l}$ was obtained in precipitation induced by $A$. sulfureus and $B$. muralis and $0.8-1.4 \mathrm{~g} / \mathrm{l}$ by $B$. atrophaeus. However, the $\mathrm{pH}$ clearly affects the amount of formed calcium carbonate and the rate of the precipitation process (Fig. 1). For all studied bacteria, the highest precipitation rate was observed in alkaline $\mathrm{pH}$ ranging between 8-9, while the lowest in $\mathrm{pH}$ about 6 . There were no statistically significant differences in the kinetics of the mineralization process in the medium whether with or without urea. A. sulfureus which in the presence of urea was characterised by three times as high precipitation rate, (0.42- 0.55 $\left.\mathrm{h}^{-1}\right)$, was the exception. Interestingly, when it comes to A. sulfureus, $\mathrm{CaCO}_{3}$ formation was observed within the first $24 \mathrm{~h}$ of the process, during the logarithmic phase 
Table 2. Parameters of bacterial growth and calcium carbonate precipitation

\begin{tabular}{|c|c|c|c|c|c|c|c|c|c|c|}
\hline \multirow{3}{*}{$\begin{array}{l}\text { Bacterial } \\
\text { strain }\end{array}$} & \multirow{3}{*}{ Factor } & \multirow{3}{*}{ Factor value } & \multicolumn{4}{|c|}{ Growth parameters } & \multicolumn{4}{|c|}{ Biomineralization parameters } \\
\hline & & & \multicolumn{2}{|c|}{ B4 without urea } & \multicolumn{2}{|c|}{ B4 with urea } & \multicolumn{2}{|c|}{ B4 without urea } & \multicolumn{2}{|c|}{ B4 with urea } \\
\hline & & & $\mathrm{T}_{\text {lag }}[\mathrm{h}]$ & $\mu_{\max }\left[\mathrm{h}^{-1}\right]$ & $\mathrm{T}_{\text {lag }}[\mathrm{h}]$ & $\mu_{\max }\left[h^{-1}\right]$ & $\mu_{\mathrm{CaCO} 3}\left[h^{-1}\right]$ & $\mathrm{Y}[\%]$ & $\mu_{\mathrm{CaCO} 3}\left[h^{-1}\right]$ & $\mathrm{Y}[\%]$ \\
\hline \multirow{4}{*}{ B. muralis } & \multirow{12}{*}{$\mathrm{pH}$} & 6 & 25.5 & 0.44 & 0 & 0.24 & 0.08 & 94.4 & 0.13 & 96.1 \\
\hline & & 7 & 0 & 0.24 & 0 & 0.40 & 0.12 & 90.8 & 0.17 & 93.0 \\
\hline & & 8 & 0 & 0.18 & 0 & 0.35 & 0.17 & 92.5 & 0.12 & 94.4 \\
\hline & & 9 & 23.9 & 3.06 & 26.1 & 0.27 & 0.18 & 91.6 & 0.12 & 96.9 \\
\hline \multirow{4}{*}{ A. sulfureus } & & 6 & 0 & 0.32 & 0 & - & 0.13 & 83.8 & 0.42 & 87.3 \\
\hline & & 7 & 0 & 0.40 & 0 & - & 0.10 & 83.7 & 0.49 & 84.9 \\
\hline & & 8 & 0 & 0.68 & 0 & - & 0.17 & 66.4 & 0.54 & 68.7 \\
\hline & & 9 & 0 & 0.69 & 0 & - & 0.18 & 80.8 & 0.55 & 83.8 \\
\hline \multirow{4}{*}{ B. atrophaeus } & & 6 & 18.9 & 2.09 & 20.9 & 0.15 & 0.11 & 32.3 & 0.09 & 32.5 \\
\hline & & 7 & 0 & 0.13 & 12.9 & 0.16 & 0.16 & 28.8 & 0.85 & 29.2 \\
\hline & & 8 & 0 & 0.26 & 0 & 0.21 & 0.87 & 38.5 & 0.22 & 38.9 \\
\hline & & 9 & 20.6 & 2.09 & 0 & 0.23 & 0.05 & 41.7 & 0.05 & 40.1 \\
\hline \multirow{3}{*}{ B. muralis } & \multirow{9}{*}{$\begin{array}{l}\text { Temperature } \\
{\left[{ }^{\circ} \mathrm{C}\right]}\end{array}$} & 25 & 0 & 0.23 & 0 & 0.18 & 0.02 & 88.8 & 0.02 & 79.1 \\
\hline & & 30 & 0 & 0.18 & 0.6 & 0.22 & 0.03 & 93.3 & 0.04 & 90.5 \\
\hline & & 37 & 8.3 & 0.21 & 0 & 0.16 & 0.08 & 93.6 & 0.06 & 97.6 \\
\hline \multirow{6}{*}{ B. atrophaeus } & & 25 & 0 & 0.12 & 0 & - & 0.03 & 85.0 & 0.76 & 98.3 \\
\hline & & 30 & 0 & 0.10 & 0 & - & 0.04 & 89.5 & 0.76 & 98.3 \\
\hline & & 25 & 0 & 0.28 & 10.2 & 0.22 & 0.07 & 61.3 & 0.02 & 58.4 \\
\hline & & 30 & 19.8 & 0.17 & 3.3 & 0.22 & 0.05 & 61.7 & 0.01 & 58.1 \\
\hline & & 37 & 0 & 0.42 & 8.0 & 0.31 & 0.05 & 49.5 & 0.30 & 39.2 \\
\hline & & 44 & 0 & 0.33 & 0 & 0.9 & 0.12 & 37.7 & 0.76 & 35.8 \\
\hline \multirow{3}{*}{ B. muralis } & \multirow{9}{*}{$\begin{array}{l}\text { Agitation } \\
\text { speed } \\
\text { [rpm] }\end{array}$} & 0 & 4.5 & 0.08 & 31.8 & 0.21 & 0.08 & 22.5 & 0.02 & 26.0 \\
\hline & & 100 & 0 & 0.19 & 18.1 & 0.26 & 0.03 & 30.0 & 0.02 & 22.3 \\
\hline & & 180 & 0 & 0.33 & 20.5 & 0.32 & 0.10 & 94.5 & 0.01 & 93.4 \\
\hline \multirow{3}{*}{ A. sulfureus } & & 0 & 24.7 & 0.15 & 0 & - & 0.04 & 5.1 & 0.09 & 95.6 \\
\hline & & 100 & 0 & 0.15 & 0 & - & 0.04 & 12.3 & 0.35 & 98.5 \\
\hline & & 180 & 0 & 0.21 & 0 & - & 0.04 & 95.6 & 0.40 & 99.3 \\
\hline \multirow{3}{*}{ B. atrophaeus } & & 0 & 22.2 & 0.06 & 0 & 0.03 & 0.03 & 18.8 & 0.45 & 4.8 \\
\hline & & 100 & 29.5 & 0.05 & 0 & 0.08 & 0.03 & 24.6 & 0.06 & 15.8 \\
\hline & & 180 & 18.4 & 0.20 & 11.8 & 0.16 & 0.09 & 45.7 & 0.07 & 38.5 \\
\hline \multirow{3}{*}{ B. muralis } & \multirow{9}{*}{$\begin{array}{l}\text { Calcium } \\
\text { source }\end{array}$} & $\begin{array}{l}\text { calcium } \\
\text { acetate }\end{array}$ & 8.6 & 0.14 & 14.3 & 0.17 & 0.15 & 90.4 & 0.10 & 95.2 \\
\hline & & $\begin{array}{l}\text { calcium } \\
\text { chloride }\end{array}$ & 0 & 0.26 & 22.6 & 0.13 & 0.02 & 8.0 & 0.04 & 14.5 \\
\hline & & $\begin{array}{l}\text { calcium } \\
\text { nitrate }\end{array}$ & 0 & 0.14 & 11.9 & 0.26 & 0.09 & 4.2 & 0.05 & 11.7 \\
\hline \multirow{3}{*}{ A. sulfureus } & & $\begin{array}{l}\text { calcium } \\
\text { acetate }\end{array}$ & 0 & 0.22 & 0 & - & 0.04 & 95.7 & 0.43 & 99.7 \\
\hline & & $\begin{array}{l}\text { calcium } \\
\text { chloride }\end{array}$ & 0 & 0.17 & 0 & - & 0.05 & 22.5 & 0.70 & 99.7 \\
\hline & & $\begin{array}{l}\text { calcium } \\
\text { nitrate }\end{array}$ & 4.8 & 0.07 & 0 & - & 0.08 & 42.2 & 0.56 & 99.4 \\
\hline & & $\begin{array}{l}\text { calcium } \\
\text { acetate }\end{array}$ & 23.1 & 0.22 & 20.8 & 0.24 & 0.06 & 34.5 & 0.11 & 32.6 \\
\hline B. atrophaeus & & $\begin{array}{l}\text { calcium } \\
\text { chloride }\end{array}$ & 15.1 & 0.28 & 7.1 & 0.09 & 0.06 & 20.0 & 0.03 & 19.7 \\
\hline & & $\begin{array}{l}\text { calcium } \\
\text { nitrate }\end{array}$ & 7.3 & - & 0 & - & 0.25 & 35.2 & 0.05 & 5.4 \\
\hline
\end{tabular}

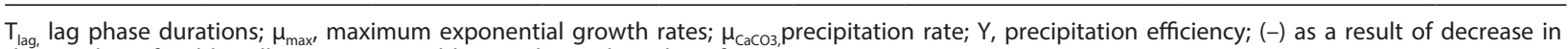
the number of viable cells it was impossible to indicate the value of $\mu_{\max }$ 
of the bacterial growth. After this time, the increase in the amount of calcium carbonate was lower, and what is more, a sudden decline in the total number of viable cells was detected. For the rest of the strains, the maximum amount of precipitated $\mathrm{CaCO}_{3}$ was obtained after $48 \mathrm{~h}$ (B. muralis and $A$. sulfureus) and $72 \mathrm{~h}$ (B. subtilis), however, the increase of insoluble $\mathrm{CaCO}_{3}$ was noted up to $120 \mathrm{~h}$ into the process. There was no significant difference in bacterial growth profiles and specific growth rates (Table 2). However, the microbiologically induced $\mathrm{CaCO}_{3}$ precipitation appeared to be correlated with the growth of the studied strains.

According to Hammes \& Verstraete (2002) and Al-Thawadi (2011) the $\mathrm{pH}$ of the environment is an important factor determining both, precipitate and solubility of the calcium carbonate. Both, the high efficiency and rate of the calcium carbonate precipitation are related to the metabolic activity of the cells, as well as the specific urease activity. The effect of $\mathrm{pH}$ between 6-7 is minor, as the bacterial cells protect the enzyme from acidity. Moreover, at neutral $\mathrm{pH}$, the predominant carbonate species in the environment are biscarbonate $\left(\mathrm{HCO}_{3}^{-}\right)$rather than carbonate $\left(\mathrm{CO}_{3}^{-}\right)$(Alhour, 2013). The activity of urease increased between $\mathrm{pH} 7.5-8.0$ and
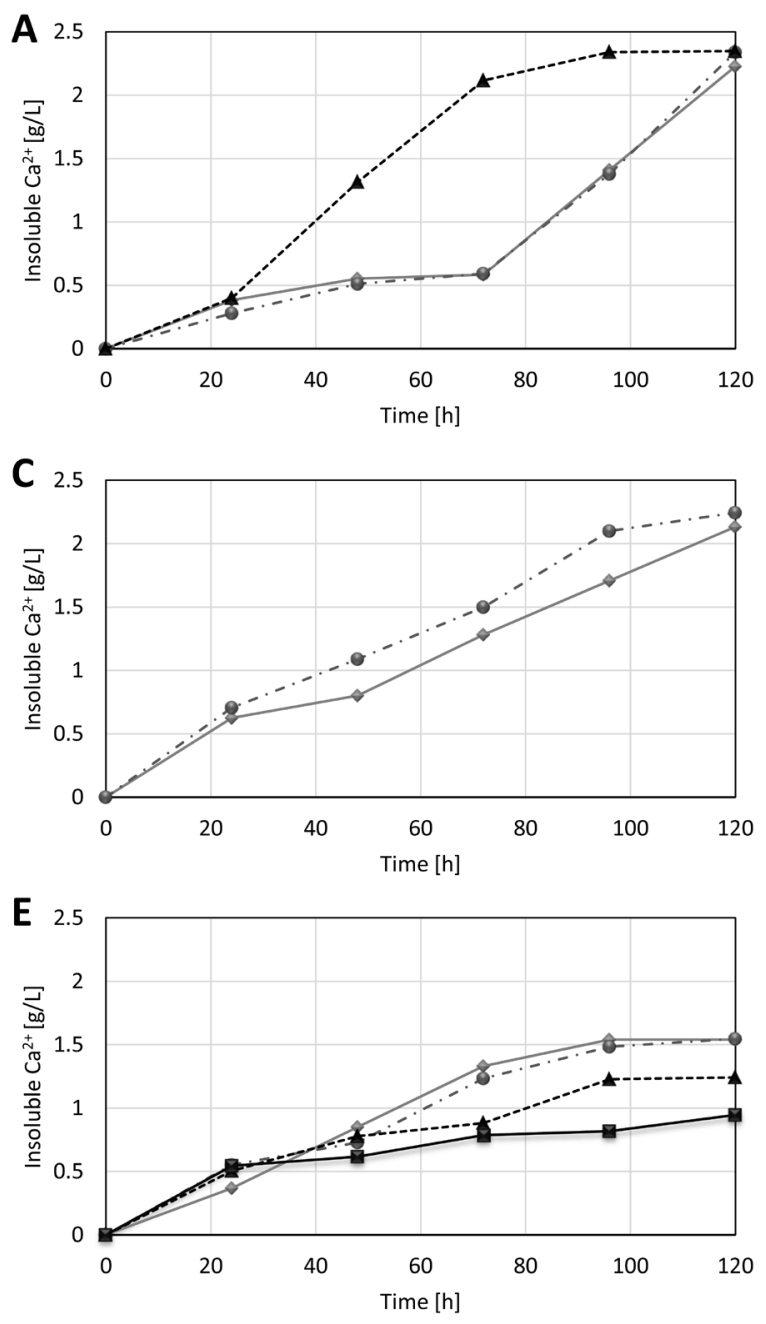

reached a maximum at $\mathrm{pH} 8.0-9.0$, whereas at above $\mathrm{pH}$ 9.0 it was slowly decreasing. The optimal $\mathrm{pH}$ for calcium carbonate precipitation induced by the studied strains is consistent with results reported by Stocks-Fischer et al. (1999) and Okwadha \& Li (2010). According to the authors, biomineralization occurs at $\mathrm{pH}$ between 8.3 and 9.0, where urease activity remains high. It is worth noting that alkaline $\mathrm{pH}$ has not always had a positive influence on microbiologically induced mineralization. With respect to microorganisms which do not show urease activity, alkaline $\mathrm{pH}$ can even inhibit calcium carbonate precipitation.

\section{Effect of temperature on biomineralization process and bacterial growth}

In the first step of this research, the growth ability in the temperature range of $25,30,37$ and $44^{\circ} \mathrm{C}$ on $\mathrm{B} 4$ medium was determined. Bacteria $B$. atrophaeus were able to grow in the widest temperature range $25-44^{\circ} \mathrm{C}$, while $B$. muralis did not reveal the ability to grow only at the highest temperature. For $A$. sulfureus, growth was only observed between $25-30^{\circ} \mathrm{C}$. For further study of the biomineralization process under the model conditions, the
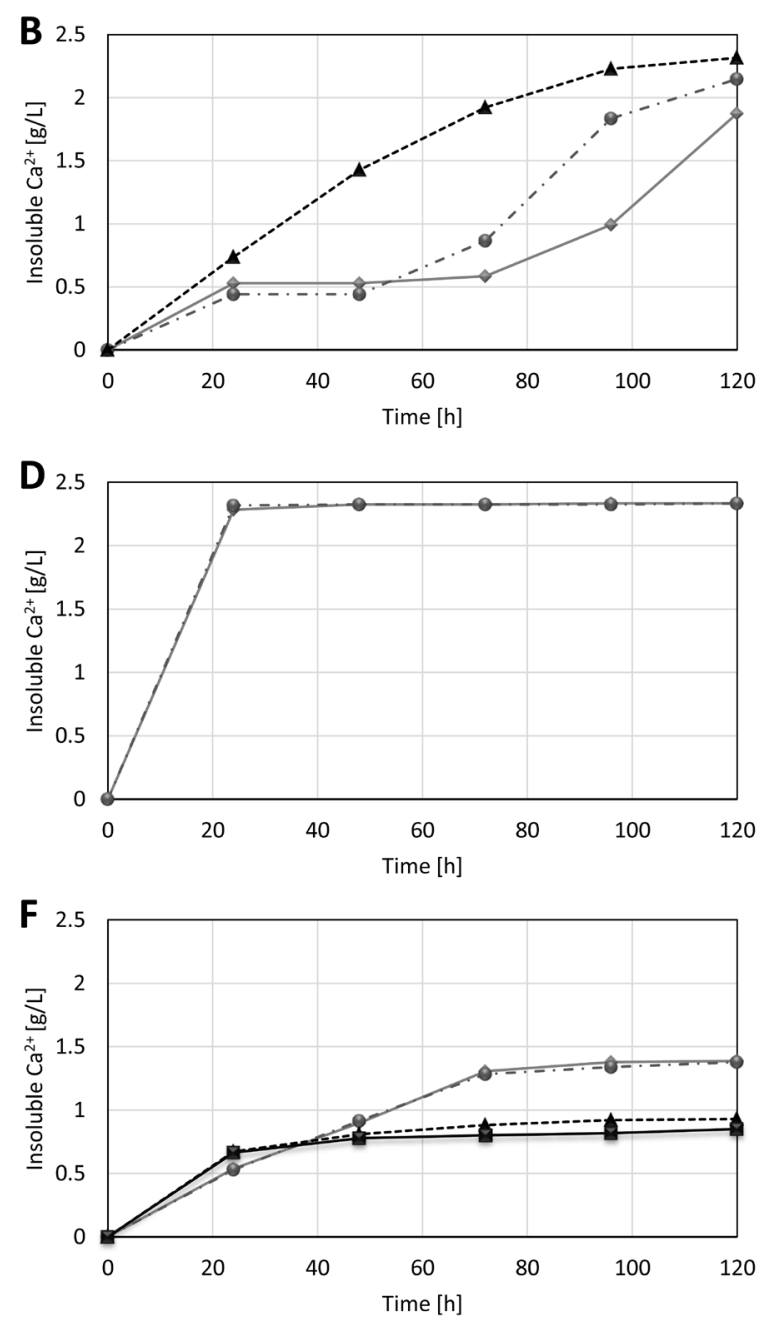

$\leadsto 25^{\circ} \mathrm{C}-0 \cdot 30^{\circ} \mathrm{C}---\cdot 37^{\circ} \mathrm{C} \rightarrow-44^{\circ} \mathrm{C}$

Figure 2. Time courses of mineralization induced by $B$. muralis

(A-B); A. sulfureus (C-D), and B. atrophaeus (E-F) in various temperatures of cultivation. Medium without urea (A, C, E) and supplemented with urea $(\mathbf{B}, \mathbf{D}, \mathbf{F})$. 

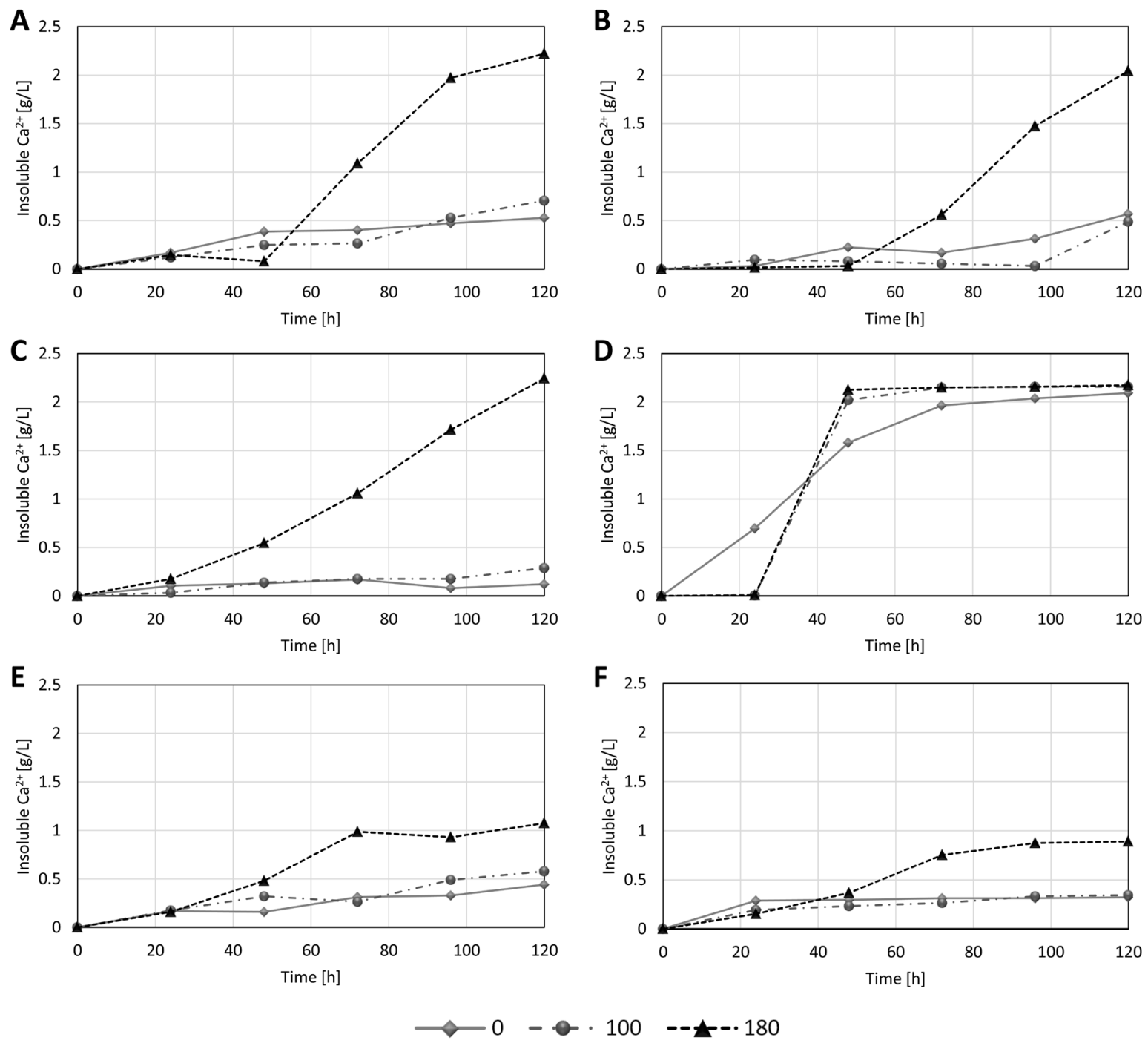

Figure 3. Time courses of mineralization induced by B. muralis (A-B); A. sulfureus (C-D), and B. atrophaeus (E-F) at various speeds of agitation.

Medium without urea (A, C, E) and supplemented with urea (B, D, F).

temperatures were selected at which the growth of microorganisms was observed.

On the basis of the results, a correlation between incubation temperature and the biomineralization process cannot be clearly evaluated (Fig. 2). The highest efficiency of this process was noted for $B$. atrophaeus and $A$. sulfureus at $25-30^{\circ} \mathrm{C}$, whereas for B. muralis it was at $37^{\circ} \mathrm{C}$. For the latter strain, the temperature did not significantly influence the amount of calcium carbonate precipitate, but at higher temperatures, the process was three times faster, and the value of $\mu$ equaled $0.08 \mathrm{~h}^{-1}$ (Table 2). The aspect deserving much interest is that, for $B$. muralis, independently of the incubation temperature, the growth rate was similar and ranged between 0.18 to $0.23 \mathrm{~h}^{-1}$, however at $37^{\circ} \mathrm{C}$, it reached its maximum. For $A$. sulfureus bacteria, medium supplementation with $2 \%$ of urea resulted in the highest efficiency, as well as the most active calcium carbonate precipitation. Among the rest of the studied strains, no statistically significant differences were observed during the processes which were held in media with or without urea in the environment (Fig. 2).

Temperature seems to have an effect on calcium carbonate precipitation. Nevertheless, the role of tem- perature as an environmental factor is still secondary in comparison to $\mathrm{pH}$. However, the optimum temperatures have a positive effect on bacterial precipitation of calcite, increasing the ability of the strain to form crystals. Baskar et al. (2006) found that $25^{\circ} \mathrm{C}$ was optimum for mineralization mediated by $B$. thuringiensis and $B$. subtilis. At lower temperatures $\left(5-15^{\circ} \mathrm{C}\right)$, carbonate precipitation started only after 15 days of incubation. As Ferris et al. (2003) and Nemati et al. (2005) pointed out, calcite precipitation rates did not vary significantly at different temperatures. Although in lower temperature the time required for biomineralization process to occur was longer due to urea hydrolysis rates, e. g. at $20^{\circ} \mathrm{C}$ generated a longer lag time before critical supersaturation when compared to $30^{\circ} \mathrm{C}$. Regardless of the applied temperature, calcite was the predominant polymorph, with aragonite and vaterite also present in trace amounts. On the other hand, as indicated by Weiss et al. (2014) when studying chemical nonbiological precipitation of $\mathrm{CaCO}_{3}$, the temperature determined the formation of different calcium carbonate polymorphs. It was observed that lower temperatures $\left(25-30^{\circ} \mathrm{C}\right)$ were favorable for vaterite formation, whereas calcite and aragonite were the preferred 

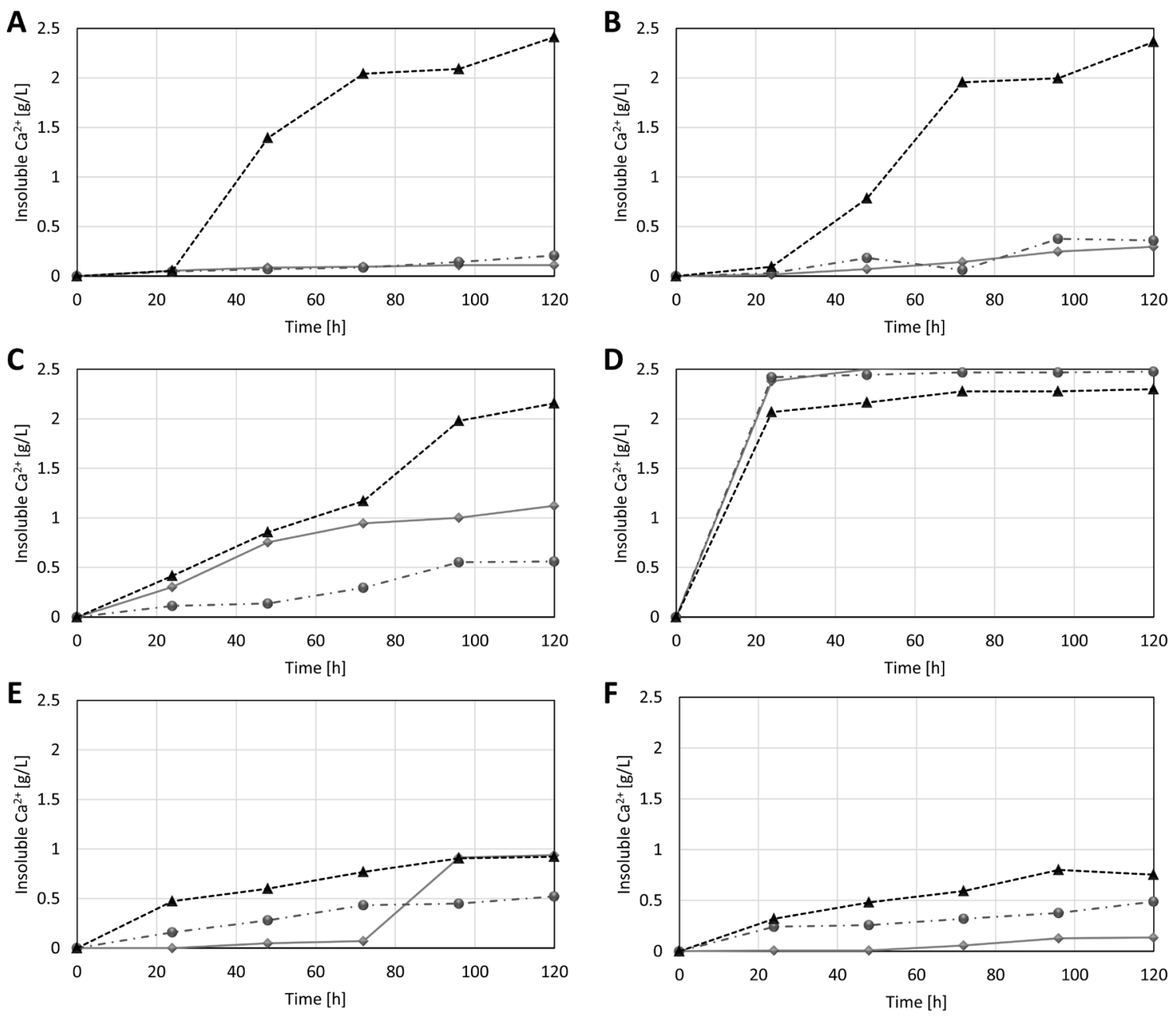

$\leadsto$ nitrate $-0-$ chloride $-\mathbf{- A - -}$ acetate

Figure 4. Time courses of mineralization induced by B. muralis (A-B); A. sulfureus (C-D), and B. atrophaeus (E-F) in the presence of different sources of calcium in the environment.

Medium without urea $(\mathbf{A}, \mathbf{C}, \mathbf{E})$ and supplemented with urea (B, D, F).

polymorphs that were formed at significantly higher temperatures, even 50 and $70^{\circ} \mathrm{C}$, respectively.

\section{The impact of agitation speed on calcium carbonate precipitation}

All of the strains considered in this study are aerobic microorganisms, therefore the source of oxygen and thus, indirectly, the speed of agitation has an important influence on their growth. On account of the results, it was assumed that the speed of agitation determined microbiologically induced mineralization (Fig. 3). For each analyzed strain, the lowest amount of precipitated calcium carbonate, between $0.12-0.52 \mathrm{~g} / \mathrm{L}$ and $0.3-0.7 \mathrm{~g} / \mathrm{L}$, was observed in the culture without agitation or when the agitation speed had been set at $100 \mathrm{rpm}$. Increasing the agitation speed to $180 \mathrm{rpm}$, resulted in over a $60 \%$ increase in the process' efficiency for B. muralis and $20 \%$ for $B$. atrophaeus, in a medium with or without urea (Table 2). A. sulfureus was the exception. In the presence of urea it effectively formed calcium carbonate (96-99\%), regardless of the agitation speed (Fig. 3). However, statistically significant differences were noted for calcium carbonate precipitation in the presence of urea. When the agitation speed was between 100-180 rpm, the precipitation rate was found to be four times as high, in comparison to the culture without stirring (Table 2).

For studied bacteria, the speed of agitation had an impact on the time courses of bacterial growth and growth rate. Although both, the biomineralization process and bacteria growth, were agitation-dependent, there was no correlation between them. For every analyzed strain, the optimum agitation speed leading to high efficiency and intensity of biomineralization was $180 \mathrm{rpm}$.

It could be inferred that for $A$. sulfureus strain, controlled mineralization was observed, rather than a microbiologically induced process. It may be evidenced by the lack of correlation between environmental factors $(\mathrm{pH}$, temperature, speed of agitation) and the kinetics of the biomineralization process. What is noteworthy, is that regardless of the process variables, after $24 \mathrm{~h}$ of cultivation the decrease in the number of viable cells was noted. Hence, it was impossible to designate the maximum growth rate in each and every conducted experiment. The significant increase in $\mathrm{pH}$ due to urea hydrolysis 

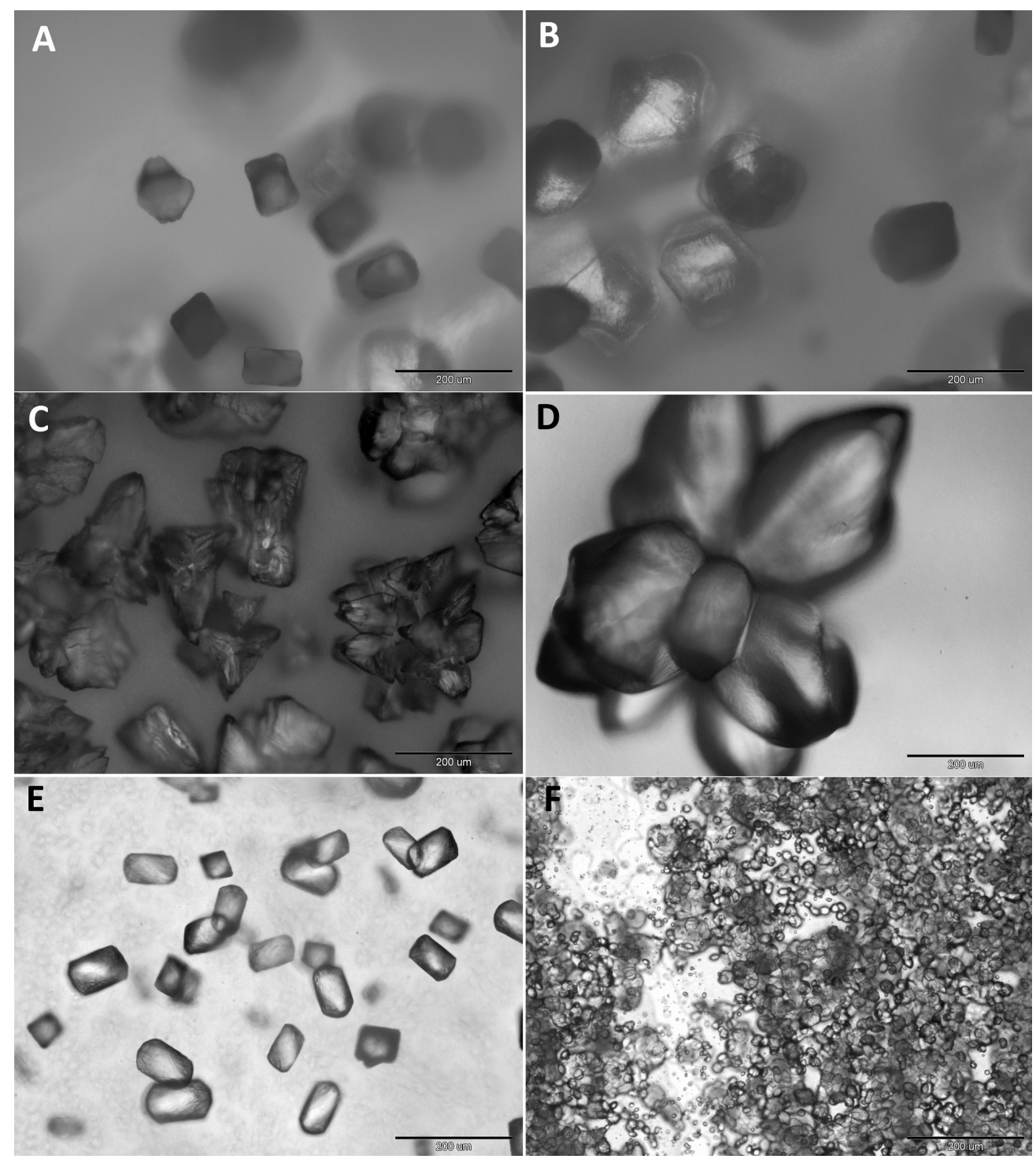

Figure 5. Morphology of calcium carbonate crystals formed by B. muralis (A-B), A. sulfureus (C-D) and B. atrophaeus (E-F) in medium without urea $(B, D, E)$ and supplemented with urea $(A, C, E)$.

could facilitate the bacterium to move on to the death phase.

\section{Biomineralization and bacterial growth profiles in presence of different calcium sources}

In order to achieve an effective mineralization mediated by bacteria, it is necessary to apply the appropriate source of calcium ions. The bacterial growth and biomineralization profiles were studied in media supplemented with different calcium sources such as: calcium acetate $\left(\mathrm{Ca}\left(\mathrm{C}_{2} \mathrm{H}_{3} \mathrm{O}_{2}\right)_{2}\right)$, calcium chloride $\left(\mathrm{CaCl}_{2}\right)$ and calcium nitrate $\left(\mathrm{Ca}\left(\mathrm{NO}_{3}\right)_{2}\right)$. The initial concentration of soluble calcium ions was between $2.5-2.7 \mathrm{~g} / \mathrm{L}$. The type of calcium source affected the microbiologically induced mineralization. For the B. muralis bacteria, the highest efficiency $(90-95 \%)$ was observed when medium was supplemented with calcium acetate, both with and without urea (Fig. 4). In the presence of calcium chloride and calcium nitrate, precipitation yield was significantly lower, $8-14.5 \%$ and $4.2-11.6 \%$, respectively. In both cases, the biomineralization process took a long time and the precipitation rate ranged between 0.2 and $0.5 \mathrm{~h}^{-1}$ (Ta- ble 2). Calcium acetate was also the most preferred calcium source in biomineralization mediated by $A$. sulfureus in medium without urea. The presence of calcium acetate resulted in a 70 and $50 \%$ higher process yield in comparison to calcium chloride and nitrate, respectively. Interestingly, for media enriched with urea, a high yield and constant rate of precipitation was observed, regardless of the applied type of calcium source. There was no significant difference in growth profiles among different media. However, the maximum exponential rate was observed in media containing calcium acetate. On the basis of our findings, it could be inferred that the optimal calcium source for the biomineralization process mediated by studied strains was calcium acetate. There were no significant differences in growth profiles among different media.

Our results confirm the observations by Lee (2003). The author performed biomineralization in medium containing calcium acetate and found that the maximized yield was $0.91 \mathrm{mg}$ of calcite. On the other hand, results obtained by Achal \& Pan (2014) revealed that the minimum calcite amount was precipitated in medium supple- 
mented with calcium oxide, whereas the maximum was with calcium chloride.

\section{Characterization of calcium carbonate crystals by microscopic analysis}

For B. atrophaeus and B. muralis, rhombohedral crystals were observed, while for $A$. sulfureus complex crystalline structures such as druses were predominant. On the basis of the microscopic analysis, the correlation between environmental parameters and the crystal morphology (size, shape, color), cannot be clearly evaluated. However, the structure and size of biocrystals were dependent on the features of the bacterial strain and the presence of urea in the environment. The biggest rhombohedral crystals, of an average size of $94.6 \times 59.5 \mu \mathrm{m}$ (B4 without urea) and $188 \times 177 \mu \mathrm{m}$ (B4 with urea), were observed in cultures of B. muralis, while the smallest, $93.5 \times 57.9 \mu \mathrm{m}$ (B4 without urea) and $21.6 \times 18.3 \mu \mathrm{m}$ (B4 with urea), for B. atrophaeus. Wang and Nilsen-Hamilton (2013) assumed that the size, morphology, orientation, composition and the localization of mineral secretion are microbial species-dependent.

\section{CONCLUSIONS}

On the basis of our results, it could be stated that under the appropriate experimental model conditions it is possible to perform microbiologically induced mineralization. The study of the biomineralization phenomenon, from the point of view of basic research, has led to clarification that the environmental factors such as $\mathrm{pH}$ of the surrounding solution, agitation speed and type of calcium source determine biomineralization. However, a correlation between incubation temperature and this process cannot be clearly evaluated. The addition of urea to the culture medium did not significantly affect the bacterial growth and the constant rate of calcium carbonate precipitation mediated by $B$. atrophaeus and $B$. muralis. For $A$. sulfureus, $B$. atrophaeus and $B$. muralis, the calcium acetate was the most preferred calcium source and the $\mathrm{pH}$ of the surrounding solution above 8.0, and agitation speed set to $180 \mathrm{rpm}$ were the most appropriate factors for the biomineralization process. Moreover, the structure and size of biocrystals depended not on the environmental conditions, but in particular on the features of the bacterial strain and the presence of urea in the environment. In the light of development of future engineering technologies involving microbially induced mineralization such as conservation of monuments, sand consolidation, and the remediation of cracked concrete, the above-mentioned results play a major role.

\section{Acknowledgements}

The authors would like to acknowledge Paulina Markowiak, MSc., for invaluable technical support, which was necessary to conduct our research.

\section{REFERENCES}

Achal V, Pan X (2014) Influence of calcium sources on microbially induced calcium carbonate precipitation by Bacillus sp. CR2. Appl Microbiol Biotechnol 173: 307-317. doi: 10.1007/s12010-014-0842-1.

Alhour MT (2013) Isolation, characterization and application of calcite producing bacteria from urea rich soils. Master Thesis of Science, Islamic University - Gaza.

Al-Thawadi SM (2011) Ureolytic bacteria and calcium carbonate formation as a mechanism of strength enhancement of sand. $J A d v S_{c i}$ Eng Res 1: 98-114.
American Public Health Association (APHA) (1989) Standard Methods for the examination of water and wastewater. 17th ed. American Public Health Association, Washington, DC.

Atlas RM (2010) Handbook of Microbiological Media, 4th ed. ASM press. Taylor and Francis group, LLC.

Baranyi J, Roberts TA (1994) A dynamic approach to predicting bacterial growth in food. Int J Food Microbiol 23: 277-294. doi:10.1016/0168-1605(94)90157-0.

Baskar S, Baskar R, Mauclaire L, McKenzie JA (2005) Role of microbial community in stalactite formation, Sahastradhara caves, Dehradun, India. Curr Sci 88: 1305-1308.

Baskar S, Baskar R, Mauclaire L, McKenzie JA (2006) Microbially induced calcite precipitation in culture experiments: Possible origin for stalactites in Sahastradhara caves, Dehradun, India. Curr Sci 1: 58-64.

Bouquet E, Boronat A, Ramos-Cormenzana A (1973) Production of calcite (calcium carbonate) crystals by soil bacteria in a general phenomenon. Nature 246: 527-529. doi:10.1038/246527a0.

Castanier S, Le Métayer-Levrel G, Perthuisot JP (1999) Ca-Carbonates precipitation and limestone genesis - the microbiologist point of view. Sediment Geol 126 (1-4): 9-23. doi: 10.1016/S00370738(99)00028-7.

De Muynck W, De Belie N, Verstraete W (2010) Microbial carbonate precipitation in construction materials: a review. Ecol Eng 36: 118136. doi:10.1016/i.ecoleng.2009.02.006.

Dhami NK, Reddy MS, Mukherjee A (2013) Bacillus megaterium mediated mineralization of calcium carbonate as biogenic surface treatment of green building materials. World J Microbiol Biotechnol 29: 2397-2406. doi: 10.1007/s11274-013-1408-z.

Ferris FG, Phoenix V, Fujita Y, Smith RW (2003) Kinetics of calcite precipitation induced by ureolytic bacteria at 10 to $20^{\circ} \mathrm{C}$ in artificial groundwater. Geochim Cosmochim Ac 67: 1701-1722. doi:10.1016/ S0016-7037(03)00503-9.

Hammes F, Boon N, Clement G, de Villiers J, Siciliano SD, Verstraete W (2003) Strain-specific ureolytic microbial calcium carbonate precipitation. Appl Environ Microbiol 69: 4901-4909. doi: 10.1128/ AEM.69.8.4901-4909.2003.

Hammes F, Boon N, Clement G, de Villiers J, Sicilliano SD, Verstraete W (2003) Molecular, biochemical and ecological characterization of a bio-catalytic calcification reactor. Appl Environ Microbiol 62: 191201. doi: 10.1007/s00253-003-1287-6.

Hammes F, Verstraete W (2002) Key roles of pH and calcium metabolism in microbial carbonate precipitation. Rev Environ Sci Biotech 1: 3-7. doi: 10.1023/A:1015135629155.

Knorre H, Krumbein KE (2000) Bacterial calcification. In Microbial sediments. Riding RE, Awramik SM eds, pp 25-31. Springer-Verlag, Berlin. doi: 10.1007/978-3-662-04036-2_4.

Konhauser K, Riding R (2012) Bacterial biomineralization. Fundament Geobiol 1: 105-130.

Lee YN (2003) Calcite production by Bacillus amyloliquefaciens CMB01. J Microbiol 41: 345-348.

Lowenstam HA, Weiner S (1989) On biomineralization. New York, NY: Oxford University Press.

Nemati M, Greene EA, Voordouw G (2005) Permeability profile modification using bacterially formed calcium carbonate: comparison with enzymic option. Process Biochem 40: 925-933. doi:10.1016/j. procbio.2004.02.019.

Okwadha GDO, Li J (2010) Optimum conditions for microbial carbonate precipitation. Chemosphere 81: 1143-1148. doi:10.1016/j.chemosphere.2010.09.066

Rivadeneyra MA, Parraga J, Delgado R, Ramos-Cormenzana A, Delgado G (2004) Biomineralization of carbonates by Halobacillus trueperi in solid and in liquid media with different salinities: crystal formation sequence. Res Microbiol 149: 277-287. doi: 10.1016/j.femsec.2003.12.008.

Sarayu K, Iyer NR, Murthy AR (2014) Exploration on the biotechnological aspect of the ureolytic bacteria for the production of the cementitious materials - a review. Appl Biochem Biotechnol 172: 23082323. doi: 10.1007/s12010-013-0686-0.

Stock-Fischer S, Galinat JK, Bang SS (1999) Microbiological precipitation of $\mathrm{CaCO}_{3}$. Soil Biol Bioch 31: 1563-1571. doi:10.1016/S00380717(99)00082-6.

Wang L, Nilsen-Hamilton M (2013) Biomineralization proteins: from vertebrates to bacteria. Front Biol 2: 234-246. doi: 10.1007/s11515012-1205-3.

Weiss CA, Torres-Cancel K, Moser RD, Allison PG, Gore ER, Chandler MQ, Malone PG (2013) Influence of temperature on calcium carbonate polymorph formed from ammonium carbonate and calcium acetate. I Nanotech Smart Mater 1: 1-6.

Young JR, Henriksen K (2003) Biomineralization within vesicles: the calcite of coccoliths. Rev Mineral Geochem 54: 189-215.

Zaika LL, Philips JG, Fanelli JS, Scullen OJ (1998) Revised model for aerobic growth of Schigella flexneri to extend the validity of predictions at temperatures between 10 and $19^{\circ} \mathrm{C}$. Int J Food Microbiol 41: 9-19. doi:10.1016/S0168-1605(98)00037-3. 